\title{
Kerjasama Imigrasi Dengan Instansi Pemerintah Dalam Penanganan Kasus Penyelundupan Manusia
}

\author{
Pratama Naoval Cardani Dhafasha ${ }^{1}$, Anggita Ndaru Nurdiyanti ${ }^{2}$, \\ Marco Edward Pontoh ${ }^{3}$ \\ ${ }^{123}$ Program Studi Hukum Keimigrasian Politeknik Imigrasi \\ 1 pratamanaufal9@gmail.com
}

\begin{tabular}{l}
\hline Keywords: \\
\hline People \\
Smuggling, \\
Immigration, \\
Transnational \\
Organized \\
Crimes \\
\hline
\end{tabular}

\begin{abstract}
The purpose of this study is to describe and analyze exploitative transnational crimes that are carried out directly or indirectly, with the aim of making profit for themselves and others. People smuggling is inseparable from illegal immigrants. This research method is normative-empirical qualitative in the Live Case Study group. The data collection technique used is by compiling questions and answers about Transnational Organized Crimes and compiling related literature that is still related to the titles and themes discussed in the study. The analysis of the data in this study is formed in the presentation of data (data display), data reduction (data reduction), and by drawing a conclusion. The results showed that the Directorate General of Immigration held a national coordination meeting with other government agencies such as the National Police, the Ministry of Religion, the Ministry of Manpower, and the National Agency for the Placement and Protection of Indonesian Migrant Workers (BNP2MI). OA surveillance is also carried out by the Directorate General of Immigration (Directorate General of Immigration) in collaboration with the National Police Security Intelligence Agency (Baintelkam). The formalization of this cooperation has been carried out in the form of a Cooperation Agreement. The conclusion in this study is prevention efforts, Immigration PPNS can make efforts to prevent the occurrence of people smuggling and trafficking in persons with Police Investigators, Ministry of Manpower Employment PPNS, BP2MI, Regional Governments based on Articles 56, 57, 58, 59 of Law no. 21 of 2007 concerning the Eradication of TP of Trafficking in Persons and Article 111 of Law no. 6 of 2011 concerning Immigration.
\end{abstract}

Kata Kunci:

Penyelundupan

Manusia,

Imigrasi,

\section{Abstrak}

Tujuan penelitian ini adalah untuk mendeskripsikan dan menganalisis tindak kejahatan transnasional yang bersifat eksploitatif yang dilakukan secara langsung maupun tidak, 
Kejahatan

Transnasional

Terorganisir dengan tujuan profit bagi diri sendiri maupun orang lain Penyelundupan manusia tidak terlepas dari imigran ilegal. Metode penelitian ini adalah kualitatif bersifat normatif-empiris dalam kelompok Live Case Study. Teknik pengumpulan data yang digunakan dengan menyusun pertanyaan dan jawaban seputar Transnational Organized Crimes dan menyusun literatur-literatur terkait yang masih berhubungan dengan judul dan tema yang dibahas di penelitian. Analisis data yang ada di penelitian ini terbentuk dalam penyajian data (data display), reduksi data (data reduction), dan dengan ditariknya suatu kesimpulan. Hasil penelitian bahwa Direktorat Jenderal Imigrasi mengadakan rapat koordinasi nasional dengan instansi pemerintah lainnya seperti Polri, Kementrian Agama, Kementerian Tenaga Kerja, serta Badan Nasional Penempatan dan Perlindungan Tenaga Kerja Indonesia (BNP2MI). Pengawasan OA pun dilakukan oleh Direktorat Jenderal Imigrasi (Ditjen Imigrasi) yang berkolaborasi dengan Badan Intelijen Keamanan (Baintelkam) Polri. Formalisasi kerjasama ini telah dilakukan dengan bentuk Perjanjian Kerjasama. Kesimpulan dalam penelitian ini adalah upaya pencegahan, PPNS Keimigrasian dapat melakukan upaya pencegahan terjadinya penyelundupan manusia dan perdagangan orang dengan Penyidik Polri, PPNS Ketenagakerjaan Kemnaker, BP2MI, Pemda berdasarkan Pasal 56, 57, 58, 59 UU No. 21 Tahun 2007 Tentang Pemberantasan TP Perdagangan Orang dan Pasal 111 UU No. 6 Tahun 2011 Tentang Keimigrasian.

\section{Pendahuluan}

Pesatnya perkembangan teknologi dewasa ini, membawa dampak positif maupun negatif. Manusia dengan sangat mudah mengakses berita dari berbagai belahan dunia dalam hitungan detik. Batas antar negara menjadi samar sehingga kejahatan lintas negara sangat rentan terjadi dewasa ini. Kemajuan teknologi memudahkan akses antar negara, sehingga terjadi kenaikan mobilitas barang maupun manusia dari satu negara ke negara lainnya, dari satu tempat ketempat lainnya. Dengan kemudahan akses dalam batas Negara ini memudahkan individu untuk memasuki suatu negara. Hal ini, memungkinkan untuk terjadinya praktik kejahatan lintas Negara yang terorganisasi (Transnasional Organized Crime).

Kejahatan transnasional terjadi, tidak hanya disebabkan karena faktor perdagangan bebas dan lemahnya penegakan hukum, tetapi juga keadaan geografis dari negara itu sendiri. Sebagai salah satu contoh, Indonesia menjadi negara yang berpotensi terjadinya kejahatan transnasional (Andi Aina Ilmih, 2017). Praktik penyelundupan orang (people smuggling) di dunia, termasuk di Indonesia, telah meningkat dalam beberapa tahun terakhir. Indonesia 
kerap dijadikan sebagai Negara Transit oleh para imigran ilegal dan Australia sebagai Negara Tujuan (destination country). Australia menjadi Negara Tujuan para imigran ilegal karena Australia meratifkasi Konvensi Pengungsi (Debby Kristin \& Dewi, 2017a).

Banyak studi migrasi menunjukkan bahwa alasan migrasi terutama karena alasan ekonomi, yaitu adanya kesempatan untuk memperoleh pendapatan, pekerjaan dan alasan lainnya yang lebih baik. Dengan melakukan migrasi merupakan cara untuk meningkatkan kualitas kehidupannya. Faktor ekonomi merupakan faktor primer yang mempengaruhi migrasi. Faktor ekonomi tersebut seperti mobilitas jabatan mobilitas sosial), upah yang lebih tinggi, kesempatan kerja yang lebih banyak dan lainnya (Ninla Elmawati Falabiba, 2019).

Kerugian yang disebabkan oleh kejahatan lintas negara yang terorganisasi tentunya merugikan banyak pihak. Kejahatan Lintas negara ini tentunya menjadi masalah nasional dan internasional yang perlu ditangani secara bersama. Indonesia sendiri sudah mendukung upaya dalam melawan kejahatan lintas negara dengan ikut menandatangani konvensi UNTOC pada tahun 2000 yang sudah ditandatangani dengan Undang-Undang Nomor 5 Tahun 2009 dengan dua protokolnya. Penyelundupan manusia (People Smuggling) adalah suatu bentuk kejahatan lintas negara yang marak beredar. Istilah Penyelundupan (smuggling) umumnya merujuk pada suatu kelompok maupun individu yang melakukan perpindahan orang-orang secara ilegal (pelanggaran terhadap konstitusi) guna menyebrangi perbatasan suatu negara demi keuntungan (Martin \& Miller, 2000).

Dengan adanya UU No 6 Tahun 2011 Tentang Keimigrasian, bisa dimanfaatkan oleh penegak hukum dengan sebaik mungkin. Dengan adanya kespesifikan sumber hukum yang didalamnya terdapat peraturan tindak pidana penyelundupan manusia, diharapkan mengamunisi penegak hukum saat menjalankan tugasnya dalam upaya pemberantasan penyelundupan manusia (people smuggling). Adapun fokus penelitian ini membahas tentang apa saja instansi pemerintah yang bekerjasama dengan imigrasi dalam melaksanaan penegakan hukum terhadap tindak pidana penyeludupan manusia dan bagaimana kerjasama yang di lakukan Imigrasi dengan Instansi pemerintah lainnya dalam melaksanakan penegakan hukum terhadap tindak pidana penyeludupan manusia.

\section{Metode}

Metode penelitian yang digunakan adalah kualitatif bersifat normatif-empiris yaitu suatu penelitian hukum yang melakukan pengkajian terkait penerapan atau pengimplementasian ketentuan dari teori-teori hukum serta hukum positif yang dimana 
melakukan penyesuaian keadaan di setiap kejadian hukum yang ada didalam masyarakat. Penelitian ini termasuk dalam kelompok Live Case Study, yakni adanya suatu approach dalam suatu fenomena hukum yang masih berlangsung prosesnya. Sumber data yang digunakan adalah data Primer dengan data hasil penelitian penulis dengan melakukan suatu tanya jawab dengan narasumber dalam Perkuliahan. Adapun perkuliahan yang dimaksud adalah Perkuliahan Transnational Organized Crimes dengan dosen pengampu mata kuliah tersebut adalah bapak ronny frankie sompie. Sedangkan untuk data sekunder diantaranya karya tulis ilmiah terdahulu, jurnal, buku, dan segala peraturan perundang-undangan yang relevan dengan kajian penelitian.

Teknik Pengumpulan Data yang dilakukan dengan menyusun susunan pertanyaan dan jawaban seputar Transnational Organized Crimes dan menyusun literatur-literatur terkait yang masih berhubungan dengan judul dan tema yang dibahas di penelitian ini. Untuk analisis data menggunakan teknik yang bersifat induktif dan berkelanjutan yang memiliki tujuan untuk memperoleh makna, menghasilkan suatu definisi , dan menciptakan konsepkonsep serta pengembangan hipotesis atau teori baru yang didapat melalui catatan lapangan, interviews, serta bahan pendukung yang lain. Analisis data yang ada di penelitian ini terbentuk dalam penyajian data (data display), reduksi data (data reduction), dan dengan ditariknya suatu kesimpulan.

\section{Hasil dan Pembahasan}

\section{Kejahatan Transnasional yang Terorganisir (Transnational Organized Crimes)}

Suatu kejahatan skala internasional atau yang menggunakan keterlibatan banyak negara dengan sifat terorganisir disebut dengan Kejahatan Transnasional atau Transnational Organized Crimes (TOC). Layaknya berbentuk seperti sebuah organisasi internasional, Kejahatan Transnasional ini lebih spesifik melakukan tindakannya dalam hal-hal ilegal yakni human trafficking, terrorism, dan yang lainnya. Perserikatan Bangsa-Bangsa (PBB) pertama kali membawakan konsep ini melalui pertemuannya di sekitar tahun 90an dengan berdiskusi terkait prevensi TOC. Ragam definisi Kejahatan Transnasional yang sangat variatif didorong dari perbedaan pengalaman, latar belakang edukasi, serta interest para ahli. Meskipun demikian, terdapat keyword yang bisa menjadi rujukan pedoman perumusan definisi kejahatan transnasional, yakni: (a) suatu tindakan yang tergolong kejahatan, terjadinya dalam skala lintas negara atau antar-negara. Faktor pendorong terjadinya kejahatan modern kini adalah kapabilitas tak terbatas untuk masuk ke dalam suatu negara, 
serta kelekatan akan berkembangnya informasi dan teknologi dengan kehidupan masyarakat. Berbagai unsur seperti perdamaian dunia yang secara langsung terancam, keamanan dan perdamaian dunia yang secara tidak langsung terancam, serta perasaan manusia yang menjadi goyah merupakan instrumen yang tercakup pada unsur internasional.

Hal ini sejalan dengan pendapat Natarajan bahwa semua kriminal adalah lokal, namun kriminalitas tersebut memiliki kelanjutan dan peristiwa tertentu. Jika peristiwa tersebut melampaui batas negara, maka hal tersebut menjadi transnasional. Eksistensi kejahatan transnasional juga merupakan implikasi dari konsekuensi natural revolusi dinamis teknologi komputer dan internet, sehingga pasar menjadi mudah dalam proses transportasi dan komunikasi (Naseh, 2019).

G.O.W. Mueller berpendapat bahwa "Kejahatan transnasional mengacu pada istilah yuridis terkait ilmu mengenai kejahatan yang dibuat oleh PBB bidang pencegahan kejahatan dan peradilan pidana guna mengidentifikasi suatu peristiwa pidana yang telah melakukan pelanggaran hukum negara-negara, melewati perbatasan internasional, maupun memberi pengaruh bagi negara lain. Dalam buku "International Criminal Law”, Bassiouni menyebutkan bahwasanya kejahatan transnasional merupakan kejahatan yang berdampak atau memiliki keterlibatan dengan masyarakat lebih dari satu negara, memiliki pengaruh bagi lebih dari satu negara, serta segala metode dan fasilitas yang digunakan telah melewati batasan teritorial suatu negara.

Perserikatan Bangsa-Bangsa telah sepakat dan menempatkan kejahatan- kejahtan yang dilakukan semasa peperangan sebagai kejahatan yang mengancam dan merugikan serta merusak tatanan kehidupan masyarakat internasional. Beberapa tindak pidana atau kejahatan tersebut di atas, antara lain adalah agresi (agression), kejahatan perang (war crimes), pembasmian etnis tertentu (genocide), pembajakan di laut (piracy), penculikan (kidnapping), dan narkotika (narkotic crimes) sudah termasuk tindak pidana yang merugikan masyarakat internasional (Sari, 2014).

Dengan demikian, kejahatan transnasional merupakan istilah yang digunakan untuk segala kejahatan yang sejatinya bersifat nasional (dalam batasan kedaulatan negara), namun pada aspek tertentu mengenai kepentingan negara lain sehingga menampilkan adanya dua negara atau lebih yang terkait atau memiliki kepentingan dalam kejahatan tersebut. Rupanya, stabilitas suatu negara menjadi terancam akibat keberadaan kejahatan lintas batas kawasan, negara, bahkan tatanan internasional ini. Geografis suatu negara yang berdekatan menjadi salah satu cikal bakal kemunculan kejahatan transnasional, diperlukan perjanjian 
mutlak negara-negara guna bisa menjatuhkan tuntutan pada pelaku tindakan pidana transnasional yang melintasi batas negara. Kaitan kejahatan transnasional hampir selalu berkenaan dengan kejahatan bermotif finansial yang memberi pengaruh pada kepentingan banyak negara. Oknumnya akan bekerja sama membentuk koalisi guna melaksanakan kejahatan negara. Berdasarkan pada argumen dari Bassiouni, harus ada tiga unsur agar kejahatan transnasional dapat dikategorikan sebagai tindak pidana internasional, yaitu: unsur kebutuhan, unsur transnasional, dan unsur internasional.

\section{Macam-Macam Kejahatan Transnasional}

Berdasarkan Undang-Undang Nomor 5 Tahun 2009 Tentang Ratifikasi United Nation Convention on Transnational Organized Crime (UNTOC), bentuk kategori yang termasuk kedalam kejahatan lintas negara adalah: (a) pencucian uang, (b) korupsi, (c) perdagangan manusia, (d) penyelundupan, (e) Imigran gelap serta Produksi, (f) Perdagangan gelap senjata api. Narkoba dan kejahatan terorisme telah diakui oleh berbagai konvensi sebagai kejahatan lintas negara. ASEAN Plan of Action to Combat Transnational Crime (Asean Pactc) menyebutkan tipe-tipe kejahatan lintas negara seperti dibawah ini: (a) perdagangan gelap narkoba, (b) perdagangan manusia, (c) Sea Piracy (Pembajakan), (d) penyelundupan senjata, (e) pencucian uang; (g) terorisme, (h) kejahatan ekonomi Internasional dan (h) kejahatan siber.

Dinamika masyarakat internasional menjadi pengiring perkembangan seluruh bentuk kejahatan lintas negara yang telah disebutkan. Apabila tidak ada upaya strategis terkait peminimalisiran maupun pencegahan mobilitas para pelaku kejahatan, maka hal ini akan kian tak terkendali. Berubahnya persepsi atau paradigma berpikir pun tentunya tidak hanya memerlukan tindakan frontal semata, namun juga sentuhan cara yang elegan. Diperlukan kerjasama yang mumpuni dalam melakukan aksi kelompok kejahatan yang terorganisir, serta guna menyediakan jasa serta barang haram. Selain itu, kapabilitas dalam berkoordinasi serta keterampilan sangat dibutuhkan pada aktivitas bisnis kejahatan ini. Apabila kita melihat, terdapat alasan yang mendorong maraknya kasus kejahatan transnasional di seluruh dunia, yakni keterbatasan persepsi. John G. Stoessinger menyatakan bahwa terdapat keterbatasan pada kemampuan manusia dalam memikirkan dan mengetahui suatu hal. Manusia cenderung menerima segala hal yang hanya sesuai dengan persepsi atau pemikiran saja, apabila suatu hal dirasa kontradiktif, maka mereka akan menolaknya. Hal tersebutlah yang memicu timbulnya konflik. 


\section{Teori Terkait dalam Transnational Organized Crimes}

a. Donald Cressey

Kejahatan terorganisir merupakan tindak kejahatan yang pada pelaksanaannya mempercayai suatu individu dalam membagi-bagi jenis pekerjaannya yang mencakup seorang pengumpul, penaksir, serta pemaksa.

b. Michael Maltz

Kejahatan terorganisir ialah aktivitas kejahatan dimana terdapat seorang individu yang setia berada di dalamnya dalam melakukan kejahatan. Kejahatan ini mencakup korupsi, monopoli, pencurian, ekonomi, serta kekejaman yang memakan korban.

c. Frank Hagan

Kejahatan terorganisir merupakan sekelompok individu yang terlibat dalam pelanggaran hukum dalam awal pelaksanaan kejahatannya guna mendapat untung secara ilegal dengan kekuatan kekuatan yang ilegal pula serta terlibat dalam tindakan memeras dan menyelewengkan uang.

Penyelundupan migran dan kejahatan perdagangan manusia selalu berkaitan dengan mobilitas manusia, baik sebagai korban maupun pelaku. Dasar konsepnya yakni mobilitas manusia ke suatu tempat dari tempat lainnya yang bertentangan dengan hukum guna mendapat untung (Santoso, 2007).

Istilah penyeludupan (smuggling) umumnya merujuk pada keuntungan yang dituju oleh suatu kelompok atau individu secara ilegal (melanggar ketetapan Undang-Undang) guna menyebrangi batasan suatu negara (Martin \& Miller, 2000). Penyelundupan Manusia, diartikan sebagai pencarian guna mendapat keuntungan finansial maupun materi lain secara langsung maupun tidak, melalui mobilitas ilegal seseorang non-penduduk ke suatu negara tanpa perizinan untuk tinggal. tinggal. Melewati perbatasan negara dengan tidak patuh terhadap perizinan atau regulasi legal yang dibutuhkan dalam memasuki wilayah disebut dengan tindakan masuk secara ilegal. (Protocol against the Smuggling of Migrants by Land, Sea, and Air, Supplementing the United Nations Convention against Transnational Organized Crimes (Protokol Menentang Penyelundupan Migran Melalui Darat, Laut, Dan Udara) Pasal 3, n.d.) Menurut (Hanson, 2007) suatu individu atau kelompok yang tinggal lebih dari batas waktu izin tinggal sahnya berlaku di suatu wilayah, atau tidak mencukupi syarat sah memasuki suatu wilayah, disebut dengan imigran gelap. 


\section{Dasar Hukum dalam Transnational Organized Crimes}

a. Undang-Undang Nomor 9 Tahun 1992 Tentang Keimigrasian;

b. Undang-Undang Republik Indonesia Nomor 15 Tahun 2009 Tentang Pengesahan Protokol Menentang Penyelundupan Migran melalui Darat, Laut dan Udara, Melengkapi konvensi Perserikatan Bangsa-Bangsa menolak Tindak Pidana Transnasional yang Terorganisir ;

c. Undang-Undang Nomor 6 Tahun 2011 Tentang Keimigrasian.

\section{Instansi Pemerintah yang Bekerjasama dengan Imigrasi dalam Melaksanakan Penegakan Hukum Terhadap Tindak Pidana Penyelundupan Manusia}

Meningkatnya arus imigran gelap tahun demi tahun. Menuntut pemerintah untuk bertindak dengan tegas mengenai permasalahan ini. Penyelundupan manusia merupakan salah satu kejahatan lintas negara yang memerlukan perhatian dari berbagai lini dalam pemerintahan. Bukan hanya menjadi perhatian dari Direktorat Imigrasi. Dalam melaksanakan penegakan hukum terhadap tindak pidana penyeludupan manusia, imigrasi tidak bisa bergerak sendiri. Tentunya memerlukan bantuan dari instasi pemerintah lainya. Ditjen Imigrasi Kemenkum dan HAM dalam menjalankan tugasnya senantiasa bekerjasama dengan instansi pemerintah lainnya Kementerian Agama, Badan Nasional Penempatan dan Perlindungan Tenaga Kerja Indonesia (BNP2MI), Kementerian Tenaga Kerja, serta Polri (Media Indonesia, 2021). Pegawai Penyidik Negeri Sipil (PPNS) Keimigrasian dapat berkoordinasi dengan penyidik Polri terkait tindak pidana penyelundupan manusia dengan berdasarkan pada Undang-Undang No 21 Tahun 2007 Tentang Tindak Pidana Perdagangan Orang dan Pasal 111 UU No 6 Tahun 2011 Tentang Keimigrasian.

\section{Kerjasama Imigrasi dengan Instansi pemerintah lainnya dalam melaksanakan penegakan hukum terhadap tindak pidana penyeludupan manusia}

Peratifikiasian pemerintah atas protokol PBB Menolak Penyelundupan Manusia Baik dari Darat, Laut, dan Udara Mendukung Konvensi PBB Menentang Kejahatan Transnasional Terorganisir dengan Undang-Undang Nomor 5 Tahun 2009 tentang Pengesahan Konvensi Perserikatan Bangsa-Bangsa Menentang Tindak Pidana Transnasional Terorganisasi dan Undang-Undang Nomor 15 Tahun 2009 tentang Pengesahan Protokol Menentang Penyelundupan Migran Melalui Darat, Laut dan Udara melengkapi Konvensi Perserikatan Bangsa-Bangsa Menentang Tindak Pidana 
Transnasional Terorganisasi, dimana pemerintah memiliki kewajiban agar menyatakan bahwa kejahatan penyelundupan manusia merupakan suatu tindak pidana, maka pemerintah merevisi Undang-Undang Imigrasi No 9 Tahun 1992 dengan mempublikasikan UndangUndang Nomor 6 Tahun 2011 Tentang Keimigrasian.

Ada bagian yang spesifik menentukan kepolisian atau jajaran imigrasi dalam menangani penyelundupan manusia pada Undang-Undang ini, yang telah berkembang secara signifikan dari Undang-Undang Nomor 9 Tahun 1992 ketika belum ada anggapan tindakan pidana terkait penyelundupan manusia yang menjadikannya hanya ditangani melalui penggunaan seluruh pasal terkait di Undang-Undang (Pramono, 2014) Negara akan menjalankan berbagai kewajiban yang ada ketika sudah melakukan ratifikasi suatu perjanjian internasional dan terikat didalamnya, yang salah satu perwujudannya adalah dengan memasukan perjanjian tersebut ke dalam hukum nasional mereka. Berikut merupakan kewajiban yang mengikat negara dalam upaya-upaya selaku bagian dari UNTOC, yaitu: a) Melakukan pembentukan Undang-Undang Khusus terkait peraturan tindak pidana transnasional terorganisir yang penetapannya ada di Pasal 5, Pasal 6, Pasal 8 dan Pasal 23 Konvensi; b) Menyusun segala aktivitas kerjasama hukum antar-negara, seperti bantuan feedback hukum tindak pidana, ekstradisi, kerjasama pelatihan dan bantuan teknis, serta kerjasama dengan sesama aparat penegak hokum (Debby Kristin \& Dewi, 2017b)

Merujuk pada pasal 1 Konvensi UNTOC (Santoso, 2007) yang memberi tujuan peningkatan kerjasama efektif internasional terkait prevensi serta melakukan pemberantasan tindak pidana transnasional terorganisir Kejahatan lintas Negara menjadi perhatian seluruh dunia. Selain dengan meningkatkan kerjasama internasional dalam melakukan pemberantasan kejahatan lintas negara yang terorganisir. Kerja sama lintas instansi pemerintah dalam negeri sangat diperlukan guna memberantas kejahatan lintas negara yang terorganisir ini. Penyeludupan manusia dengan menggunakan modus operandi mempekerjakan pekerja migran Indonesia (PMI) ke luar negeri cukup sering ditemui dalam pelaksanaan dilapangan. Faktor meningkatnya penyelundupan manusia di Indonesia adalah awamnya masyarakat terkait kejahatan penyelundupan manusia bermodus mempekerjakan (PMI) keluar negeri, dan keperluan ekonomi. Kehidupan yang layak serta status ekonomi merupakan alasan yang acap kali digunakan imigran yang menyelundup (smuggler) (Deby Kristin \& Dewi, 2018). 
Konsen dari para individu yang ingin diselundupkanlah yang biasanya mendorong terjadinya penyeludupan manusia. Kualitas dan sifat persetujuan merupakan hal dasar yang membedakan Penyelundupan Manusia dengan Perdagangan Orang, konsen yang didapat dalam perdagangan orang adalah dengan melalui pemaksaan, penipuan, kekerasan, dsb., sementara selalu ada konsen pemindahan dalam penyelundupan manusia. Dalam aspek kepentingan, eksploitasi merupakan tujuan utama dari perdagangan orang, sementara tujuan penyelundupan manusia adalah untuk secara ilegal memindahkan orang (Risfananda et al., 2019). Penegakkan hukum terhadap tindak pidana penyeludupan manusia tentunya memerlukan kerjasama dari berbagai instansi pemerintah. (Ditjen Imigrasi) Kementerian Hukum dan HAM merangkul pemerintah daerah serta instansi lainnya guna meningkatkan tingkat waspada serta prevensi tindak pidana perdagangan dan penyelundupan manusia.

Salah satu upaya kerjasama yang dilakukan dalam upaya pemberantasan tindak penyeludupan manusia yaitu Direktorat Jenderal Imigrasi mengadakan rapat koordinasi nasional dengan instansi pemerintah lainnya seperti Polri, Badan Nasional Penempatan dan Perlindungan Tenaga Kerja Indonesia (BNP2TKI), Kementerian Tenaga Kerja, dan Kementerian Agama. Terdapat sejumlah poin yang disetujui pada pertemuan tersebut, yaitu pengupayaan prevensi ketika mengajukan paspor di kantor imigrasi, mencegah di tempat keluar masuknya seperti TPI, serta pengantisipasian jalur ilegal perbatasan laut dan darat dengan kerjasama lembaga, kantor, serta pemerintah daerah setempat. Kemudian, mensosialisasikan masyarakat dengan penggunaan media sosial, media massa, seminar di desa/kelurahan, kabupaten/kota, sekolah/kampus, dan kunjungan dinas. Ada pula kesepakatan penegakan hukum secara pro-justitia, pemberian sanksi pidana dan administrasi pada pelaku penempatan, sponsor, dan penyelenggara(Media Indonesia, 2021). Pengawasan OA pun dilakukan oleh Direktorat Jenderal Imigrasi (Ditjen Imigrasi) yang berkolaborasi dengan Badan Intelijen Keamanan (Baintelkam) Polri. Formalisasi kerjasama ini telah dilakukan dengan bentuk Perjanjian Kerjasama antara Ditjen Imigrasi Kemenkumham dan Baintelkam POLRI, Nomor: B/70/IX/2017; IMI-UM.01.01-3075 tahun 2017 tentang Kerjasama dalam Pengawasan Orang Asing (Batulicin, 2019).

Tindak Pidana penyeludupan manusia berdasarkan Pasal 120 (1) UU No 6 Tahun 2011 dengan bunyi “Tiap-tiap individu dengan tujuan mencari keuntungan secara langsung maupun tidak, bagi diri sendiri maupun orang lain, dengan menggandeng suatu kelompok maupun individu yang terorganisir maupun tidak, tanpa adanya legalitas hak masuk maupun keluar wilayah Indonesia dan/atau negara lain dimana tidak adanya hak yang sah bagi sang 
individu memasuki wilayah tersebut, dengan penggunaan dokumen sah atau palsu, atau tanpa adanya penggunaan dokumen perjalanan, baik melewati pemeriksaan imigrasi atau tidak, dipidana akibat penyelundupan manusia dengan putusan minimal 5 (lima) tahun dan maksimal 15 (tahun) tahun serta pidana denda minimal Rp. 500.000.000,- (lima ratus juta rupiah) dan maksimal Rp. 1.500.000.000,- (satu milyar lima ratus juta rupiah)" merupakan bentuk kriminalisasi yang dilakukan pemerintah Indonesia dalam undang-undang keimigrasian. Menurut pasal 111 UU No. 6 Tahun 2011 Tentang Keimigrasian "PPNS Keimigrasian dapat menjalankan kerja sama guna menyelidiki tindak pidana keimigrasian bersama lembaga penegak hukum dalam dan luar negeri, sejalan dengan ketetapan Peraturan Perundang-Undangan maupun perjanjian internasional yang oleh Pemerintah Republik Indonesia telah diakui.

Maka seperti PPNS keimigrasian ketika melaksanakan tugas penegakan hukum tindak pidana penyelundupan manusia dapat bekerjasama dengan penyidik POLRI sebagaimana bunyi dari pasal yang telah disebutkan diatas. Sedangkan dalam upaya pencegahan PPNS Keimigrasian dapat melakukan upaya pencegahan terjadinya penyelundupan manusia dan perdagangan orang dengan Penyidik Polri, PPNS Ketenagakerjaan Kemnaker, BP2MI, Pemda berdasarkan Pasal 56, 57, 58, 59 UU No. 21 Tahun 2007 Tentang Pemberantasan TP Perdagangan Orang dan Pasal 111 UU No. 6 Tahun 2011. upaya pencegahan melalui: Menunda pemberian paspor bagi WNIdan menunda pemberangkatan ke luar negeri bagi WNI di TPI. Pejabat imigrasi juga perlu memperhatikan penerapan pasal 89 ayat (3) dan pasal 133 huruf a dan huruf c UU No.6 tahun 2011 untuk bisa melaksanakan ketentuan pasal 1 butir 32 yang dijabarkan dalam pasal 120 UU No. 6 tahun 2011 guna memperkuat upaya pencegahan, sehingga tidak terjadi korban kejahatan transnasional terorganisasi khususnya yang berkaitan dengan tindak pidana penyelundupan manusia dan perdagangan orang. Ini bagian dari perlindungan terhadap saksi serta korban, kejahatan transnasional terorganisasi di masa depan. "Perlu diketahui bahwa modus pengiriman atau perdagangan WNI keluar negeri saat ini entah dengan dalih tenaga kerja, misi keagamaan, misi kebudayaan dan lain-lain, pada umumnya melalui suatu badan hukum atau korporasi (Santoso, 2007).

Pejabat Imigrasi selain menunda pemberian paspor dan keberangkatan PMI. Perlu melakukan evaluasi terhadap koorporasi dan mempertimbangkan untuk memasukannya dalam daftar hitam, sehingga tindak pidana penyeludupan manusia dapat diminimalisasi dan tidak ada pengulangan dikemudian hari. Daftar hitam korporasi yang telah dibuat dapat 
dimasukan kedalam SIMIKIM sebagai tindakan pengawasan keimigrasian yang tegas. Kerjasama Imigrasi dengan instansi pemerintah lainya dan pelaksanaan tugas pejabat imigrasi yang berdasarkan dengan UU No 6 Tahun 2011 dilakukan untuk menegakan hukum dan mencegah terjadinya penyeludupan dikemudian hari.

\section{Pelaksanaan Kerjasama Internasional berdasarkan UNCATOC dalam Perspektif Keimigrasian}

Pencegahan dan penyelesaian kasus kejahatan transnasional terorganisir dilakukan oleh Setiap Negara dengan cara melakukan Kerjasama Internasional. Sesuai dengan arahan yang diberikan dalam Peraturan tentang Kejahatan Transnasional yang terorganisir, dalam hal ini adalah UNCATOC yaitu dilakukannya Kerjasama tingkat internasional. Adapun bentuk dari Kerjasama Internasional tersebut berbeda - beda, dan dalam prakteknya tentunya adanya suatu Program dan Batasan yang dilakukan sehingga dengan demikian maka Kejahatan Transnasional yang Terorganisir dapat dicegah dan diatasi.

Pembahasan terkait Pelaksanaan Kerjasama Internasional berdasarkan UNCATOC akan lebih ditekankan dalam Perspektif Keimigrasian. Tentunya Kejahatan Transnasional yang diorganisir tidak luput jauh dari Konteks Keimigrasian, sehingga dengan demikian maka akan banyak sekali permasalahan terkait Kejahatan Transnasional yang terorganisir yang beririsan langsung dengan Hal Keimigrasian. Contohnya adalah Perdagangan Orang dan Penyelundupan Manusia yang dimana kedua kasus tersebut termasuk kedalam kategori Kejahatan Transnasional yang Terorganisir dan Juga kasus tersebut merupakan kasus yang berhubungan dengan Keimigrasian, baik di Indonesia maupun Luar Negeri.

Bentuk kerjasama Indonesia dalam Menangani kasus Kejahatan Transnasional yang terorganisir salah satunya adalah Pemerintah Indonesia sepakat untuk bekerjasama dengan Commissioner for Refugee (UNHCR), dengan didukung oleh Angkatan Laut Republik Indonesia (ALRI), serta Australian Federal Police (AFP). Adapun pelaksanaan kerjasama yang dilakukan bersama UNHCR adalah dengan menyelenggarakan program AustralianIndonesian Partnership for Justice:

a. Memperbaiki Sistem peradilan dalam pemberian suatu pelayanan penyelesaian sengketa;

b. Memperbaiki kapasitas dan sistem teknis badan penuntutan dalam proses kasus korupsi; 
c. Meningkatkan akses informasi hukum, khususnya mengenai anti-korupsi dan Hak Asasi Manusia bagi publik;

d. Terdapatnya perbaikan dialog kebijakan antara masyarakat sipil, pemerintah Republik Indonesia dan Dewan Perwakilan Rakyat RI.

Selain kerjasama di atas, Indonesia yang dalam hal ini adalah Keimigrasian Indonesia melaksanakan kerjasama bilateral dengan Australia. Sebagai salah satu upaya memberantas migrasi ilegal, Komunikasi bilateral Indonesia-Australia sangatlah krusial. Alasan diadakannya kerja sama bilateral antara Indonesia dengan Australia tersebut adalah dikarenakan banyaknya Migran Iegal yang berkeinginan untuk pergi ke Australia, tetapi berdiam dan tinggal di Indonesia. Sehingga dengan demikian Kerjasama terkait Sistem Cegah dan Tangkal yang ada di Indonesia dinilai sangat penting untuk menekan angka Migrasi Ilegal yang terjadi. Kemitraan Indonesia dengan Dinas Imigrasi Australia dalam sistem CEKAL adalah contoh keeratan kerjasama keduanya terkait perihal peningkatan keamanan perbatasan.

Salah satu bentuk lain kerjasama di Imigrasi Indonesia di tingkat Internasional terkait penanganan kasus Kejahatan Transnasional Terorganisir adalah melakukan kerjasama Indonesia-International Organization for Migration (IOM). Organisasi Internasional untuk Migrasi atau yang biasa dikenal dengan IOM memiliki upaya untuk memastikan migrasi ditangani dengan teratur dan tertib, serta manusiawi yang tentunya meningkatkan pemberian bantuan kemanusiaan bagi para imigran yang memerlukan, dan kerjasama problematika migrasi. Termasuk dalam hal ini adalah bantuan bagi para pengungsi dan pengungsi internal. Adapun strategi yang digunakan untuk memberantas migrasi ilegal adalah dengan melakukan gabungan dan mengelaborasi menggunakan edukasi serta prevensi, baik dalam lingkup nasional atau internasional.

Adapun bentuk kerjasama Internsional yang dilakukan oleh Imigrasi Indonesia dengan Beberapa Negara dan Lembaga Internasional tentunya memiliki tujuan utama yaitu untuk Menangani dan Mencegah terjadinya kasus Kejahatan Transnasional yang Terorganisir. Selain kerjasam hal yang dilakukan Imigrasi Indonesia adalah dengan melaukan Pengawasan Keimigrasian. Pengawasan keimigrasian dilakukan oleh Imigrasi dan dapat menemukan indikasi adanya kasus People Smuggling serta Aparat dari Kepolisian sesuai dengan pasal 107 Undang - Undang Nomor 6 tahun 2011 Tentang Keimigrasian yakni melaksanakan pengecekan dini serta menelaah status hukum yang di dalamnya memiliki keterlibatan, baik sebagai orang yang diselundupkan atau pelaku. 


\section{Kesimpulan}

Penyelundupan manusia merupakan suatu kegiatan pencarian keuntungan bagi diri sendiri maupun orang lain secara langsung maupun tidak, dengan merangkul individu atau kelompok lain dengan terorganisir maupun tidak, atau memberi perintah orang lain agar membawakan individu atau kelompok dengan terorganisir maupun tidak, tanpa adanya hak yang sah untuk masuk maupun keluar wilayah Indonesia dan/atau negara lain dimana tidak adanya hak bagi orang yang disebutkan untuk memasuki wilayah dengan sah, baik melalui penggunaan dokumen sah atau palsu, atau tanpa pengunaan Dokumen Perjalanan, baik melewati pengecekan imigrasi atau tidak. Salah satu upaya kerjasama yang dilakukan dalam upaya pemberantasan tindak penyeludupan manusia yaitu Direktorat Jenderal Imigrasi mengadakan rapat koordinasi nasional dengan instansi pemerintah lainnya seperti Polri, Kementrian Agama, Kementerian Tenaga Kerja, serta Badan Nasional Penempatan dan Perlindungan Tenaga Kerja Indonesia (BNP2MI). Pengawasan OA pun dilakukan oleh Direktorat Jenderal Imigrasi (Ditjen Imigrasi) yang berkolaborasi dengan Badan Intelijen Keamanan (Baintelkam) Polri. Formalisasi kerjasama ini telah dilakukan dengan bentuk Perjanjian Kerjasama. Dalam upaya pencegahan, PPNS Keimigrasian dapat melakukan upaya pencegahan terjadinya penyelundupan manusia dan perdagangan orang dengan Penyidik Polri, PPNS Ketenagakerjaan Kemnaker, BP2MI, Pemda berdasarkan Pasal 56, 57, 58, 59 UU No. 21 Tahun 2007 Tentang Pemberantasan TP Perdagangan Orang dan Pasal 111 UU No. 6 Tahun 2011 Tentang Keimigrasian.

\section{Daftar Pustaka}

Andi Aina Ilmih. (2017). Analisis Kebijakan Keimigrasian dalam Upaya Pencegahan Penyelundupan Orang dan Imigran Gelap di Indonesia. Seminar Nasional Hukum Universitas Negeri Semarang, 3(1), 135-148. file://D:/Referensi/kons 5/20931Article Text-41695-1-10-20180124.pdf

Batulicin. (2019). optimalisasi penegakan hukum keimigrasian melalui perjanjiankerjasama. Imigrasi.Go.Id.

Hanson, G. H. (2007). The Economic Logic of Illegal Migration. Council Special Reports (CSR). Council on Foreign Relations.

Kristin, Debby, \& Dewi, C. T. I. (2017a). Tindak Pidana Kejahatan Penyelundupan Manusia. Padjadjaran Journal of International Law, 1(1), 100. http://download.garuda.ristekdikti.go.id/article.php?article=1024421\&val=15664\&t itle=Tindak Pidana Kejahatan Penyelundupan Manusia People Smuggling di 
Indonesia Tanggug Jawab Indonesia dan Australia

Kristin, Debby, \& Dewi, C. T. I. (2017b). Tindak Pidana Kejahatan Penyelundupan Manusia (People Smuggling) di Indonesia:Tanggug Jawab Indonesia dan Australia”.

Kristin, Deby, \& Dewi, C. T. I. (2018). Tindak Pidana Kejahatan Penyelundupan Manusia (People Smuggling) di Indonesia:Tanggug Jawab Indonesia dan Australia”.

Martin, P., \& Miller, M. (2000). Smuggling and Trafficking: A Conference Report. International Migration Review, 34(3), 969-975.

Media Indonesia. (2021). politik dan hukum/93798/imigrasi-gandeng-instansi-laincegahpenyelundupan-manusia. https://mediaindonesia.com/politik-danhukum/93798/imigrasi-gandeng-instansi-lain-cegahpenyelundupan-manusia diakses pada hari Selasa, 21 September 2021 pukul $14.00 \mathrm{WIB}$

Naseh, M. (2019). Karakteristik Pelaku Kejahatan Transnasional Terorganisir di Indonesia dan Eropa. Jurnal Hubungan Internasional, 8(1). https://doi.org/10.18196/hi.81144

Ninla Elmawati Falabiba. (2019). UPAYA PEMERINTAH INDONESIA DALAM MENANGANI MASALAH IMIGRAN ILEGAL YANG MENUJU AUSTRALIA TAHUN 2012-2015. JOM FISIP, 3(2), 1-15.

Pramono, P. (2014). ANALISIS YURIDIS TERHADAP TINDAK PIDANA PENYELUNDUPAN MANUSIA BERDASARKAN UNDANG-UNDANG NOMOR 6 TAHUN 2011 TENTANG KEIMIGRASIAN (Analisis Putusan Pengadilan Negeri Wonosari Nomor : 135/Pid.Sus/2014/PN.Wno) (2014): 127.

Risfananda, A. N. N., Elim, I., Gerungai, \& Natalia, Y. T. (2019). Analisis Perhitungan Pemotongan dan Pelaporan Pajak Penghasilan atas Pembelian Bahan Baku terhadap Pedagang Pengumpul pada PT. Delta Pasific Indotuna. Going Concern: Jurnal Riset Akuntansi, 14(4). Sam Ratulangi, Manado.

Santoso, I. (2007). Perspektif Imigrasi dalam UNTOC.

Sari, I. (2014). Kejahatan-Kejahatan Internasional (Tindak Pidana Internasional) Dan Peranan International Criminal Court (Icc) Dalam Penegakan Hukum Pidana International. Jurnal Ilmiah Hukum Dirgantara, 6(1), 38-65. https://doi.org/10.35968/jh.v6i1.114

Protocol against the Smuggling of Migrants by Land, Sea, and Air, Supplementing the United Nations Convention against Transnational Organized Crimes (Protokol Menentang Penyelundupan Migran Melalui Darat, Laut, dan Udara) Pasal 3. 